\title{
Oxygen isotope variations in granulite-grade iron formations: constraints on oxygen diffusion and retrograde isotopic exchange *
}

\author{
Z.D. Sharp ${ }^{1 * *}$, J.R. O’Neil ${ }^{2 * * *}$, and E.J. Essene ${ }^{1}$ \\ ${ }^{1}$ Department of Geological Sciences, University of Michigan, Ann Arbor, MI 48109 \\ ${ }^{2}$ United States Geological Survey, MS 937, 345 Middlefield Rd., Menlo Park, CA 94025
}

\begin{abstract}
The oxygen isotope ratios of various minerals were measured in a granulite-grade iron formation in the Wind River Range, Wyoming. Estimates of temperature and pressure for the terrane using well calibrated geothermometers and geobarometers are $730 \pm 50^{\circ} \mathrm{C}$ and $5.5 \pm$ $0.5 \mathrm{kbar}$. The mineral constraints on fluid compositions in the iron formation during retrogression require either very $\mathrm{CO}_{2}$-rich fluids or no fluid at all. In the iron formation, isotopic temperature estimates from quartz-magnetite fractionations are controlled by the proximity to the enclosing granitic gneiss, and range from $500^{\circ} \mathrm{C}\left(\Delta_{\mathrm{qz}-\mathrm{mt}}=10.0 \%\right)$ within 2-3 meters of the orthogneiss contact to $600^{\circ} \mathrm{C}$ $\left(\Delta_{\mathrm{qz}-\mathrm{rtt}}=8.0 \%\right)$ farther from the contact. Temperature estimates from other isotopic thermometers are in good agreement with those derived from the quartz-magnetite fractionations.
\end{abstract}

During prograde metamorphism, the isotopic composition of the iron formation was lowered by the infiltration of an external fluid. Equilibrium was achieved over tens of meters. Closed-system retrograde exchange is consistent with the nearly constant whole-rock $\delta^{18} \mathrm{O}_{\mathrm{wr}}$ value of $8.0 \pm 0.6 \%$. The greater $\Delta_{\mathrm{qz}-\mathrm{mt}}$ values in the iron formation near the orthogneiss contact are most likely due to a lower oxygen blocking temperature related to greater exchangeability of deformed minerals at the contact. Cooling rates required to preserve the quartz-magnetite fractionations in the central portion of the iron formation are unreasonably high $\left(\sim 800^{\circ} \mathrm{C} / \mathrm{Ma}\right)$. In order to preserve the $600^{\circ} \mathrm{C}$ isotopic temperature, the diffusion coefficient $D$ (for $\alpha$ quartz) should be two orders of magnitude lower than the experimentally determined value of $2.5 \times 10^{-16} \mathrm{~cm}^{2} / \mathrm{s}$ at $833 \mathrm{~K}$. There are no values for the activation energy $(Q)$ and pre-exponential diffusion coefficient $\left(D_{0}\right)$, consistent with the experimentally determined values, that will result in reasonable cooling rates for the Wind River iron formation. The discrepancy between the diffusion coefficient inferred from the Wind River terrane and that measured experimentally is almost certainly due to the enhancement of exchange by the presence of water in the laboratory experiments. Cooling rate estimates were also determined for iron formation retrograded under water-rich conditions.

\footnotetext{
* Contribution 441 from the Mineralogical Laboratory, University of Michigan

** Present address: Geophysical Laboratory, Carnegie Institution of Washington, 2801 Upton St, N.W. Washington, DC 20008, USA *** Present address: Department of Geological Sciences, University of Michigan, Ann Arbor, MI 48109, USA
}

Offprint requests to: Z.D. Sharp
Application of the experimentally determined data to these rocks results in a reasonable cooling rate estimate, supporting the conclusion that the presence of water greatly enhances oxygen diffusion.

\section{Introduction}

Oxygen isotope fractionations between cogenetic minerals are a sensitive indicator of formational temperatures for many rocks. However, temperature estimates in high-grade metamorphic rocks using this method are typically lower than estimates made from other thermometers (e.g. Anderson 1967; Shieh 1974; Rumble 1982; Bowman and Ghent 1985; Valley 1986). This discrepancy has been ascribed either to errors in the calibration of the isotopic thermometer or to continued isotopic exchange during cooling.

Possible mechanisms of retrograde isotopic exchange are oxygen self diffusion and recrystallization. The phenomenon of oxygen isotope exchange involves bond breaking and recrystallization, but the term recrystallization is used here to describe a process of solution and redeposition. Exchange between a crystal and a dry gas (e.g. $\mathrm{O}_{2}, \mathrm{CO}_{2}$ ) must take place by the mechanism of oxygen self-diffusion. Alternatively, the process of recrystallization mobilizes oxygen so that pure oxygen self diffusion is no longer the rate limiting step in retrograde exchange. The relative importance of oxygen self diffusion and recrystallization to retrograde oxygen isotope exchange is difficult to assess, and both probably occur during retrogression in natural systems (e.g. Matthews et al. 1983a; Giletti 1985). A fluid phase enhances intercrystalline diffusion rates (Griggs 1967, 1974; Blacic and Christie 1984; Simpson and Segall 1984) and may enhance intracrystalline oxygen diffusion as well (e.g. Yund and Anderson 1974, 1978; Krylov 1982; Cole et al. 1983; Giletti and Yund 1984). Therefore, the degree of retrograde exchange is most likely enhanced by deformation and the presence of a fluid phase. The observed isotopic fractionations between mineral pairs are likely to reflect the temperature of deformation (Kerrich et al. 1977) and/or equilibration with retrograde fluids rather than the peak prograde equilibrium partitioning between phases.

In rapidly cooled rocks, diffusion stops, or blocks in, at higher temperatures than in slowly cooled terranes (Giletti 1986a). The cooling history of a terrane could be constrained if accurate experimental diffusion rates were available, and if the grain size, isotopic ratios, and degree of recrystallization of all minerals were known. In order to evaluate retrograde isotopic effects it is advantageous to 
investigate a lithology that is both simple mineralogically and has a large isotopic fractionation between coexisting phases. Metamorphosed iron formations satisfy both of these criteria. Granulite facies iron formations consist primarily of quartz, magnetite and pyroxene (or olivine), and the oxygen isotope fractionation between quartz and magnetite is larger than for any other common mineral pair (O'Neil 1986). Oxygen isotope measurements were made on coexisting minerals obtained from granulite facies banded iron formation in the Wind River Range, Wyoming, in order to assess the degree of recrystallization and fluid migration during retrogression, and to evaluate the feasibility of stable isotope methods for estimating cooling rates.

\section{Geology of the iron formation at Rocking Horse Lake}

The Wind River Mountain Range in western Wyoming consists of a large northwest trending Archean block bounded by the Wind River fault to the southwest (Berg and Romberg 1966; Smithson et al. 1980) and a thick sequence of Paleozoic sediments to the northeast (Richmond 1945) (Fig. 1). The crystalline basement consists predominantly of granitic gneisses and migmatites that are crosscut by pegmatites and intruded by granitic plutons (Oftendahl 1953) dated at 2550-2700 Ma (Bassett and Giletti 1963; Naylor et al. 1970; Stuckless et al. 1985). Throughout the range, there are small blocks or lenses of amphibolites, peridotites, metagabbros, quartzites, paragneisses, and banded iron formations hosted in the orthogneiss (Worl et al. 1984). The iron formation, or taconite, considered in this study was described by Worl (1968) and consists of dismembered blocks or boudins of metamorphosed banded iron formation hosted by extensive migmatitic orthogneisses. This iron formation surrands Rocking Horse Lake (U.S.G.S. topographic map. Gannet Peak Quadrangle, 1:100000 series, 1978), and is preserved as a group of lenticular pods, ranging from $<1$ meter to several hundred meters in length and tens of meters in width. Primary sedimentary bedding is preserved as pyroxene-, magnetiteand quartz-rich layers, and parallels the elongate direction of the iron formation boudins (Fig. 2). The iron formation consists mainly of quartz, orthopyroxene and magnetite, with lesser amounts of plagioclase, olivine, garnet, clinopyroxene, hornblende, biotite, potassium feldspar and grunerite. At the contact between the orthogneiss and iron formation there is occasionally a poorly preserved biotite reaction rind $2-7 \mathrm{~cm}$ thick.

The orthogneiss consists of leucocratic and melanocratic components, resulting in a migmatitic layering parallel to the elongate direction of the iron formation boudins. The felsic portion consists predominantly of quartz, plagioclase and potassium feldspar, with lesser amounts of biotite, hornblende and cummingtonite. Orthopyroxene is preserved within 5 centimeters of the iron formation. The melanocratic portion of the migmatite is predominantly hornblende and plagioclase. There are minor pegmatites, but no late granitic plutons in the immediate vicinity of the iron formation at Rocking Horse Lake.

Peak metamorphic conditions were determined using well calibrated geothermometers and geobarometers (Sharp and Essene 1984). Temperature estimates are $730 \pm 50^{\circ} \mathrm{C}$ based on two-feldspar thermometry (Haselton et al. 1983), garnet-clinopyroxene exchange thermometry (Ellis and Green 1979) and garnet-orthopyroxene thermometry (Sen and Bhattacharya 1984; Lee and Ganguly 1988). Pressure estimates are $5.5 \pm 0.5 \mathrm{kbar}$ at $730^{\circ} \mathrm{C}$ based on the equilibrium assemblages orthopyroxene-quartz-olivine (Bohlen and Boettcher 1981), garnet-quartz-orthopyroxene-plagioclase (Bohlen et al. 1983a), garnet-aluminosilicate-quartz-plagioclase (Koziol and Newton 1986) and garnet-rutile-quartz-sillimanite-ilmenite (Bohlen 1983c).

The presence and composition of a retrograde fluid is strictly limited by a combination of various mineral stabilities. Preserved pyroxene and a lack of grunerite constrains $\mathrm{H}_{2} \mathrm{O}$ activities by the reaction

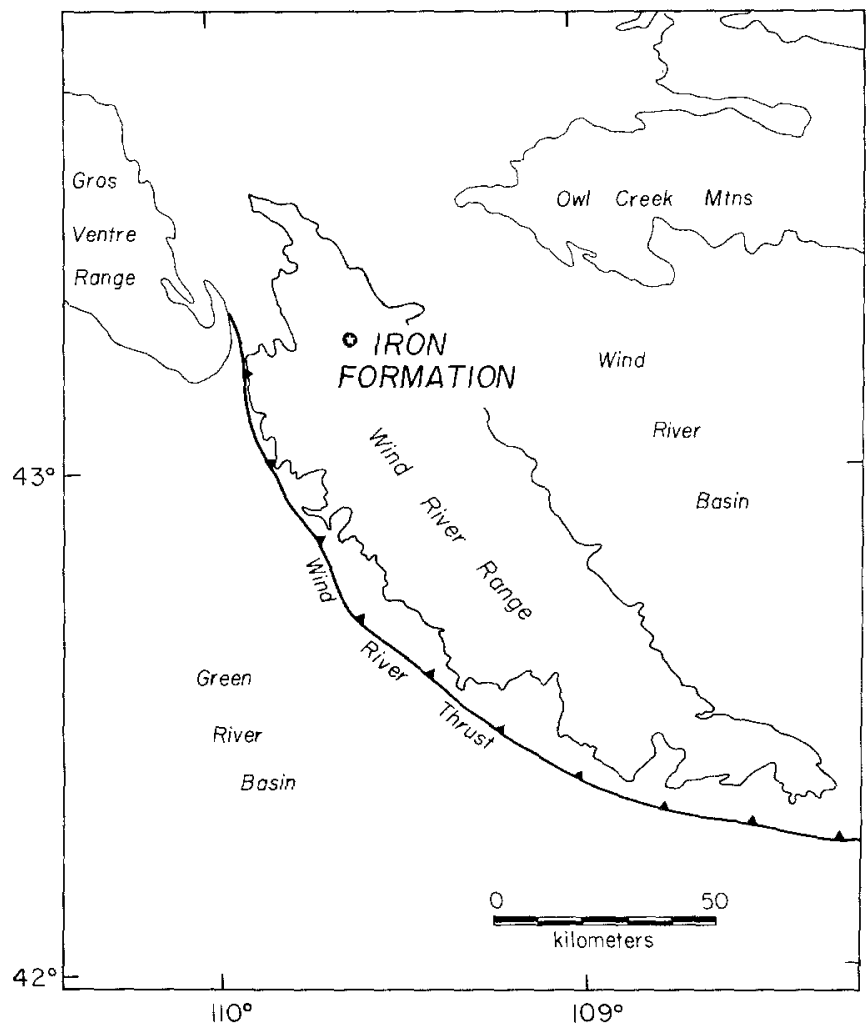

Fig. 1. Location map of the Wind River Iron Formation in western Wyoming and surrounding features

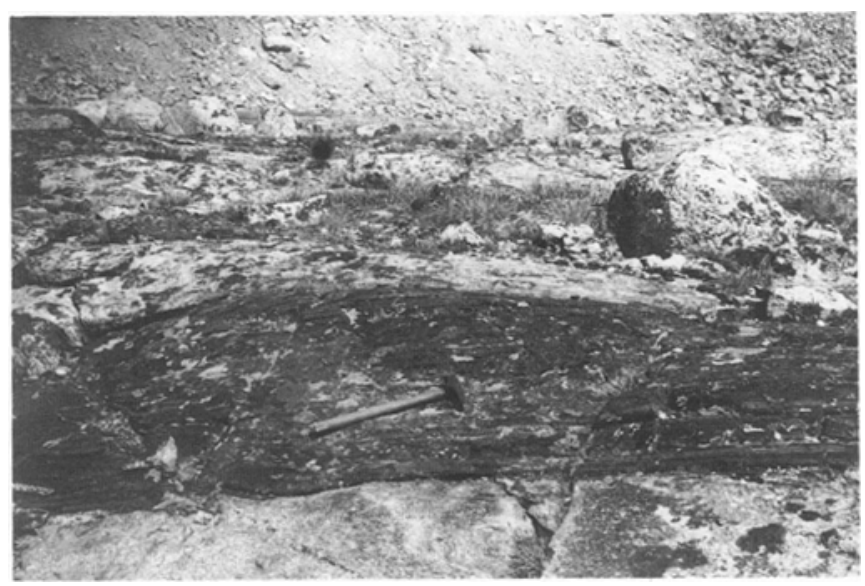

Fig. 2. Iron formation boudin in the Rocking Horse Lake Iron Formation hosted by orthogneiss. Bedding is well preserved and follows the elongate direction of the boudin. (Lighter upper "bed" grass)

$7 \mathrm{FeSiO}_{3}+\mathrm{SiO}_{2}+\mathrm{H}_{2} \mathrm{O}=\mathrm{Fe}_{7} \mathrm{Si}_{8} \mathrm{O}_{22}(\mathrm{OH})_{2}$ ferrosilite quartz water grunerite

The stability field of this reaction was determined using the heat capacity data of Bohlen et al. (1983 b) and the experimental reversals for the reactions

$2 \mathrm{Fe}_{7} \mathrm{Si}_{8} \mathrm{O}_{22}(\mathrm{OH})_{2}=7 \mathrm{Fe}_{2} \mathrm{SiO}_{4}+9 \mathrm{SiO}_{2}+2 \mathrm{H}_{2} \mathrm{O}$ grunerite fayalite quartz water

and

$2 \mathrm{FeSiO}_{3}=\mathrm{Fe}_{2} \mathrm{SiO}_{4}+\mathrm{SiO}_{2}$ ferrosilite fayalite quartz 


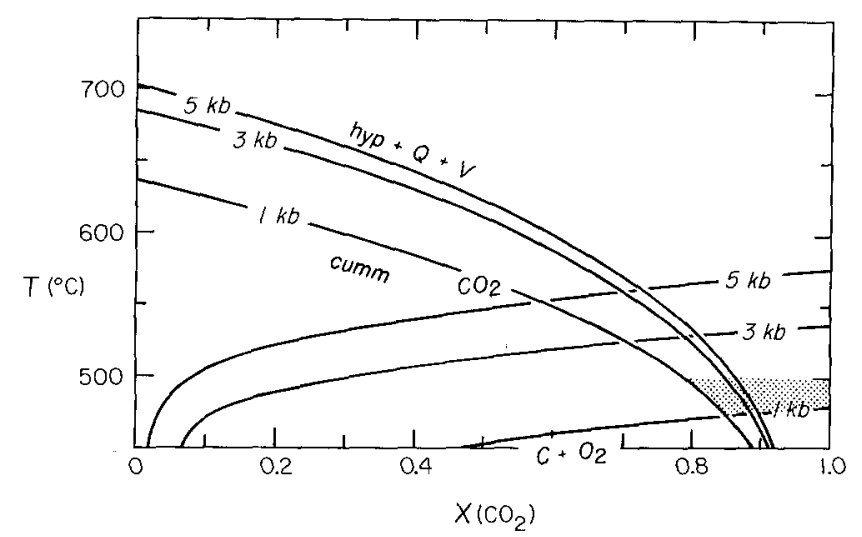

Fig. 3. $T-X$ diagram showing the stability field of graphite at $F M Q$ and the position of reaction (1) at three different pressures. The shaded area illustrates the stability field of hyp- $Q-V$ without graphite at $1 \mathrm{kbar}$. At $3 \mathrm{kbar}$, there is no fluid-present stability field that will preserve pyroxene and not stabilize graphite at $500^{\circ}$ C. Abbreviations: hypersthene (hyp), quartz $(Q)$, vapor (V), cummingtonite (cumm), graphite (C)

of B.W. Evans (unpubl.) (reaction 2) and Bohlen et al. (1980) (reaction 3). Compositions of coexisting grunerite $\left(\mathrm{gr}_{76}\right)$ and orthopyroxene $\left(\mathrm{fs}_{81}\right)$ and simple ideal mixing models allow calculation of the mole fraction $\mathrm{H}_{2} \mathrm{O}$, which must be less than 0.4 at $600^{\circ} \mathrm{C}$ and 0.2 at $500^{\circ} \mathrm{C}$ (Fig. 3). The maximum stability of graphite was calculated following the procedure of French (1966) for the $f \mathrm{O}_{2}$ constrained by the buffering assemblage ferrosilite-magnetitequartz. The lack of grunerite and graphite place strict limits on the chemistry of the retrograde fluid (Fig. 3). At $600^{\circ} \mathrm{C}$, a CO${ }_{2}$-rich fluid is required to preserve pyroxene and at $500^{\circ} \mathrm{C}$ rapid decompression and a very $\mathrm{CO}_{2}$-rich fluid phase is required to preserve pyroxene and not stabilize graphite (Fig. 3). Alternatively, if the terrane was dry $\left(P_{\text {fluid }} \ll P_{\text {total }}\right)$ during retrogression, the preserved mineralogy in the iron formation would have remained stable over a wide range of pressures and temperatures. The fluid inclusions in the iron formation at Rocking Horse Lake are too small to study optically, and cannot be used to test the above alternatives. There are several small ( $<1$ meter) iron formation boudins that have been totally hydrated. All pyroxene in these lenses has been converted to coarse grunerite, and these samples may have been saturated with respect to a water-rich fluid during retrogression.

\section{Analytical procedures}

Oxygen isotope measurements were made of mineral separates and whole-rock samples using the chlorine trifluoride extraction procedure of Borthwick and Harmon (1982). Sample sizes were chosen so as to liberate about $160 \mu \mathrm{mol}$ of $\mathrm{O}_{2}$ gas (e.g. $10 \mathrm{mg}$ quartz). Each set of extractions included two quartz standards [NBS-28 $\left(\delta^{18} \mathrm{O}_{\mathrm{qz}}=9.6 \%\right)$ or Ottawa Sand $\left.\left(\delta^{18} \mathrm{O}_{\mathrm{qz}}=9.8 \%\right)\right]$. All analyses were replicated and have an average error of less than $\pm 0.2 \%$ Quartz was magnetically separated and cleaned in a concentrated HF solution for $30 \mathrm{~s}$. All other minerals were separated magnetically, followed by heavy liquid separation, ultrasonic cleaning and final hand-picking. Separate purity is $>98 \%$ for all phases.

\section{Oxygen isotope results}

Hand samples were collected on traverses made perpendicular to bedding across iron formation boudins, and included the enclosing granitic gneiss. The $\delta^{18} \mathrm{O}$ values were determined on selected separates of magnetite $(\mathrm{mt})$, pyroxene (px) and garnet (gt) within the iron formation and on whole rock (wr) samples in both the iron formation and the orth- ogneiss. The $\delta^{18} \mathrm{O}_{\mathrm{qz}}$ was determined for all samples (Table 1). The $\delta^{18} \mathrm{O}_{\mathrm{wr}}$ values are remarkably uniform at $8.0 \pm 0.6 \%$ in both the orthogneiss and iron formation. Isotopic ratios of quartz and magnetite vary within the iron formation, and are related to distance from the orthogneiss. Data for traverses across two boudins are plotted in Fig. 4. The $\delta^{18} \mathrm{O}_{\mathrm{qz}}$ values in the orthogneiss are $9.3 \pm 0.3 \%$, with several samples lying outside this range. The $\delta^{18} \mathrm{O}_{\mathrm{qz}}$ values in the iron formations are $10.8 \pm 0.2 \%$ within $2-3$ meters of the orthogneiss contact and drop to $10.0 \pm 0.2 \%$ in the central portion of the iron formation. The profile of the $\delta^{18} \mathrm{O}_{\mathrm{mt}}$ data is opposite to that of the quartz data, with $\delta^{18} \mathrm{O}$ values of $0.9 \pm 0.1 \%$ near the orthogneiss contact and increasing to $1.9 \pm 0.3 \%$ in the central portions of the iron formation.

Temperature estimates based on the isotopic fractionation between quartz and magnetite $\left(\Delta_{\mathrm{qz}-\mathrm{mt}}\right)$ were determined using the calibration of Matthews et al. (1983b) based on the quartz-water fractionation calibrations of Matsuhisa et al. (1979) and a revised magnetite-water calibration of O'Neil (1963) (Table 2). The isotopic data for this mineral pair correspond to $500^{\circ} \mathrm{C}$ at the margin of the iron formation and $600^{\circ} \mathrm{C}$ in the central portion of the iron formation. Temperature estimates from other mineral pair fractionations are similar (Fig. 5, Table 2).

The isotopic data for the two small iron formation lenses inferred to have retrograded under water-rich conditions (Traverses 1 and 5) are given in Table 1. The $\delta^{18} \mathrm{O}_{\mathrm{qz}}$ data for Traverse 5 are nearly constant in both the granitic gneiss and the iron formation. The $\delta^{18} \mathrm{O}_{\mathrm{qz}}$ data for Traverse 1 are more erratic, ranging from $9-10 \%$ in the orthogneiss and $10-11.5 \%$ in the iron formation. Isotopic temperature estimates from quartz-magnetite fractionations are uniformly low at $510-550^{\circ} \mathrm{C}$.

\section{Prograde isotope exchange}

\section{Pre-metamorphic conditions}

There is no way to completely characterize the isotopic systematics that preceded peak metamorphism because of limited constraints that can be placed on the isotopic compositions of the unmetamorphosed precursors. Even in the least metamorphosed iron formations it is not possible to completely reconstruct the original mineralogy of the unmetamorphosed equivalent (Klein 1983). The two most common iron formation types, the carbonate facies and silicate-oxide facies, have very similar major and trace element chemistries (Davy 1983), differing predominantly in the amounts of $\mathrm{CO}_{2}$ and $\mathrm{H}_{2} \mathrm{O}$. During metamorphism, these volatiles are lost, making distinction of the precursor impossible. However, the final isotopic composition of a granulite facies iron formation will be very similar regardless of which sequence of prograde metamorphic reactions is followed, so that the degree of exchange and fluid infiltration accompanying metamorphism can be evaluated.

In the silicate-oxide facies iron formations, the predominant mineralogy of the lowest facies iron formations consists of chert, magnetite, and hematite, with lesser amounts of hydrated iron silicates (greenalite or minnesotaite). A rough estimate of the $\delta^{18} \mathrm{O}_{\mathrm{wr}}$ of an unmetamorphosed iron formation can be made if the mineralogy is considered to consist only of quartz and magnetite (maximum 35 wt. $\% \mathrm{Fe})$. For typical pre-metamorphic values of 
Table 1. Oxygen isotope data for four separate traverses across iron formation boudins $(1,2,5,7)$. Two traverses were made across boudin 1 (A-M, 1-8), and three traverses were made across boudin 2 (A-R, 1-13, T-Z). Abbreviations: wr-whole rock, qz-quartz, $m t$-magnetite, $p x$-pyroxene, gn-garnet

\begin{tabular}{|c|c|c|c|c|c|c|c|c|c|c|c|c|}
\hline ID \# & $\begin{array}{l}\delta^{18} \mathrm{O} \\
\text { wr }\end{array}$ & $\begin{array}{l}\delta^{18} \mathrm{O} \\
\mathrm{qz}\end{array}$ & $\begin{array}{l}\delta^{18} \mathrm{O} \\
\mathrm{mt}\end{array}$ & $\begin{array}{l}\delta^{18} \mathrm{O} \\
\mathrm{px}\end{array}$ & $\begin{array}{l}\delta^{18} \mathrm{O} \\
\mathrm{gn}\end{array}$ & $\begin{array}{l}\text { rock* } \\
\text { type }\end{array}$ & $X^{* *}$ & ID \# & $\begin{array}{l}\delta^{18} \mathrm{O} \\
\mathrm{qz}\end{array}$ & $\begin{array}{l}\delta^{18} \mathrm{O} \\
\mathrm{mt}\end{array}$ & $\begin{array}{l}\text { rock } \\
\text { type }\end{array}$ & $X$ \\
\hline $2-A$ & - & 9.3 & - & - & - & $\mathrm{GG}$ & 5.5 & $1-\mathrm{A}$ & 9.1 & & $\mathrm{GG}$ & 4.50 \\
\hline 2-B & - & 9.3 & - & - & - & $\mathrm{GG}$ & 4.0 & $1-C$ & 9.9 & - & $\mathrm{GG}$ & 0.12 \\
\hline $2-\mathrm{C}$ & 8.2 & 9.7 & - & -- & - & $\mathrm{GG}$ & 0.8 & $1-D$ & 10.4 & - & BIF & 0.18 \\
\hline $2-D$ & 8.5 & 9.5 & - & - & - & $\mathrm{GG}$ & 0.1 & $1-\mathrm{E}$ & 11.1 & 1.2 & BIF & 0.42 \\
\hline $2-E$ & 7.9 & 10.6 & 0.9 & 6.8 & 6.4 & BIF & 0.1 & $1-F$ & 10.8 & - & BIF & 0.68 \\
\hline $2-\mathrm{F}$ & 7.9 & 10.9 & 0.8 & - & - & $\mathrm{BIF}$ & 0.8 & $1-G$ & 11.5 & 2.4 & $\mathrm{BIF}$ & 0.42 \\
\hline $2-G$ & 7.0 & 10.1 & 2.3 & - & - & BIF & 4.9 & $1-\mathrm{H}$ & 9.9 & - & BIF & 0.09 \\
\hline $2-\mathrm{H}$ & 8.0 & 9.9 & 1.9 & 6.9 & 6.7 & BIF & 6.4 & 1-J & 10.2 & - & $\mathrm{GG}$ & 0.09 \\
\hline $2-\mathrm{J}$ & - & 10.4 & 1.7 & - & - & BIF & 6.1 & $1-\mathrm{M}$ & 9.8 & - & $\mathrm{GG}$ & 4.38 \\
\hline $2-K$ & 7.9 & 11.0 & - & - & - & BIF & 1.5 & $1-1$ & 9.0 & - & GG & 6.00 \\
\hline 2-M & 7.8 & 10.9 & 0.9 & - & - & $\mathrm{BIF}$ & 0.3 & $1-2$ & 10.2 & - & $\mathrm{GG}$ & 0.15 \\
\hline $2-\mathrm{N}$ & - & 10.7 & 1.6 & - & - & BIF & 1.1 & $1-3$ & 10.1 & 0.7 & BIF & 0.12 \\
\hline $2-\mathrm{O}$ & 6.4 & 9.7 & -0.8 & - & - & $\mathrm{BIF}$ & 0.1 & $1-4$ & 10.5 & 0.5 & BIF & 0.72 \\
\hline 2-P & - & 9.2 & - & - & - & $\mathrm{GG}$ & 0.1 & 1.5 & 10.3 & 0.4 & BIF & 0.15 \\
\hline 2-Q & - & 9.0 & - & - & - & $\mathrm{GG}$ & 0.6 & $1-6$ & 9.9 & -0.1 & BIF & 0.03 \\
\hline $2-\mathrm{R}$ & - & 9.3 & - & - & - & GG & 5.2 & $1-7$ & 10.1 & - & $\mathrm{GG}$ & 0.36 \\
\hline $2-1$ & - & 9.8 & - & - & - & $\mathrm{GG}$ & 7.6 & $1-8$ & 10.1 & - & GG & 1.35 \\
\hline $2-2$ & 7.5 & 9.1 & - & - & - & $\mathrm{GG}$ & 3.0 & & & & & \\
\hline $2-3$ & - & 9.6 & - & - & - & GG & 0.2 & $5-1$ & 9.4 & - & $\mathrm{GG}$ & 0.04 \\
\hline $2-4$ & - & 10.1 & - & 6.5 & - & $\mathrm{BIF}$ & 0.1 & $5-2$ & 9.2 & - & BIF & 0.02 \\
\hline $2-5$ & - & 10.9 & - & - & - & BIF & 1.5 & $5-3$ & 9.2 & - & BIF & 0.04 \\
\hline $2-6$ & - & 10.0 & 2.1 & 7.1 & - & BIF & 5.5 & $5-5$ & 9.5 & - & $\mathrm{BIF}$ & 0.02 \\
\hline $2-8$ & - & 10.0 & - & - & - & $\mathrm{BIF}$ & 4.9 & & & & & \\
\hline $2-9$ & 7.6 & 9.8 & 2.0 & $\ldots$ & - & BIF & 2.4 & $7-1$ & 9.6 & - & $\mathrm{GG}$ & 7.6 \\
\hline $2-10$ & - & 10.7 & - & - & - & BIF & 0.1 & $7-2$ & 9.0 & - & $\mathrm{GG}$ & 1.5 \\
\hline $2-11$ & - & 9.2 & - & - & - & GG & 0.3 & $7-3$ & 9.3 & - & GG & 0.1 \\
\hline $2-12$ & - & 8.8 & - & - & - & $\mathrm{GG}$ & 3.0 & $7-4$ & 10.0 & - & $\mathrm{BIF}$ & 0.1 \\
\hline $2-13$ & - & 9.1 & - & - & - & GG & 5.5 & $7-6$ & 10.7 & - & BIF & 2.1 \\
\hline $2-T$ & 7.1 & 10.2 & - & - & - & $\mathrm{BIF}$ & 6.7 & $7-7$ & 10.0 & - & BIF & 2.9 \\
\hline $2-U$ & - & 9.8 & - & - & - & $\mathrm{BIF}$ & 4.8 & $7-8$ & 9.5 & - & BIF & 4.1 \\
\hline $2-V$ & - & 11.1 & - & - & - & $\mathrm{BIF}$ & 3.5 & $7-9$ & 9.9 & - & $\mathrm{BIF}$ & 3.8 \\
\hline $2-W$ & - & 10.4 & - & - & - & BIF & 2.7 & $7-10$ & 10.3 & - & BIF & 3.8 \\
\hline $2-X$ & - & 9.1 & - & - & - & GG & 2.7 & $7-11$ & 11.7 & - & $\mathrm{BIF}$ & 0.6 \\
\hline $2-Y$ & - & 10.6 & - & 6.5 & - & BIF & 1.7 & $7-12$ & 10.9 & - & BIF & 0.1 \\
\hline \multirow[t]{3}{*}{$2-Z$} & - & 10.4 & - & - & - & $\mathrm{GG}$ & 0.2 & $7-13$ & 10.0 & - & $\mathrm{GG}$ & 0.1 \\
\hline & & & & & & & & $7-14$ & 9.9 & & GG & 1.1 \\
\hline & & & & & & & & $7-15$ & 9.0 & & $\mathrm{GG}$ & 3.0 \\
\hline
\end{tabular}

* $\mathrm{GG}=$ Granitic gneiss, $\mathrm{BIF}=$ Banded iron formation

** distance in meters from nearest lithologic contact

$\delta^{18} \mathrm{O}_{\mathrm{qz}}=20$ to $24 \%$ and $\delta^{18} \mathrm{O}_{\mathrm{mt}}=-13$ to $-9 \%$ (Perry et al. 1978), the $\delta^{18} \mathrm{O}_{\mathrm{wr}}$ is $13-17 \%$. The conversion of the hydrated silicates to pyroxene will not lower the $\delta^{18} \mathrm{O}_{\mathrm{wr}}$ to the present value of $8 \%$, as the fractionation between the silicate and vapor phase is very small at high temperatures. Similarly, the formation of pyroxene from quartz and magnetite could only lower the $\delta^{18} \mathrm{O}_{\mathrm{wr}}$ if the $\delta^{18} \mathrm{O}$ of the evolved oxygen were very high.

In the carbonate facies, the potential isotopic shifts caused by decarbonation of iron carbonates during metamorphism must be considered. The $\delta^{18} \mathrm{O}_{\mathrm{wr}}$ could be lowered by fractionation during decarbonation reactions, but the maximum shift in the $\delta^{18} \mathrm{O}_{\mathrm{wr}}$ from the reaction

$\mathrm{FeCO}_{3}+\mathrm{Fe}_{2} \mathrm{O}_{3}=\mathrm{Fe}_{3} \mathrm{O}_{4}+\mathrm{CO}_{2}$

siderite hematite magnetite

is small because the maximum amount of siderite and hematite is governed by the constraint of no more than 35 total $w \mathrm{t} \% \mathrm{Fe}$ in the iron formation. The greatest possible reduction in the $\delta^{18} \mathrm{O}_{\mathrm{wr}}$ will be only $2 \%$ assuming ideal Rayleigh fractionation conditions (e.g. Valley 1986). Clearly, infiltration of an external metamorphic or magmatic fluid is required to explain the reduced $\delta^{18} \mathrm{O}_{\mathrm{wr}}$ values preserved in the granulite facies iron formation.

\section{Peak-metamorphic conditions}

The isotopic compositions of minerals during peak metamorphism could be used to evaluate the degree of isotopic homogenization and the scale of fluid infiltration if these data could be recovered. Unfortunately, isotopic compositions reset during cooling, and the $\delta^{18} \mathrm{O}$ value of any mineral at peak metamorphic conditions can never be determined with certainty. However, these data can be estimated if the present isotopic composition of each mineral and the mineral modes are known, and if it is assumed that neither the mode nor $\delta^{18} \mathrm{O}_{\mathrm{wr}}$ has changed during retrogression. First, 
$g$
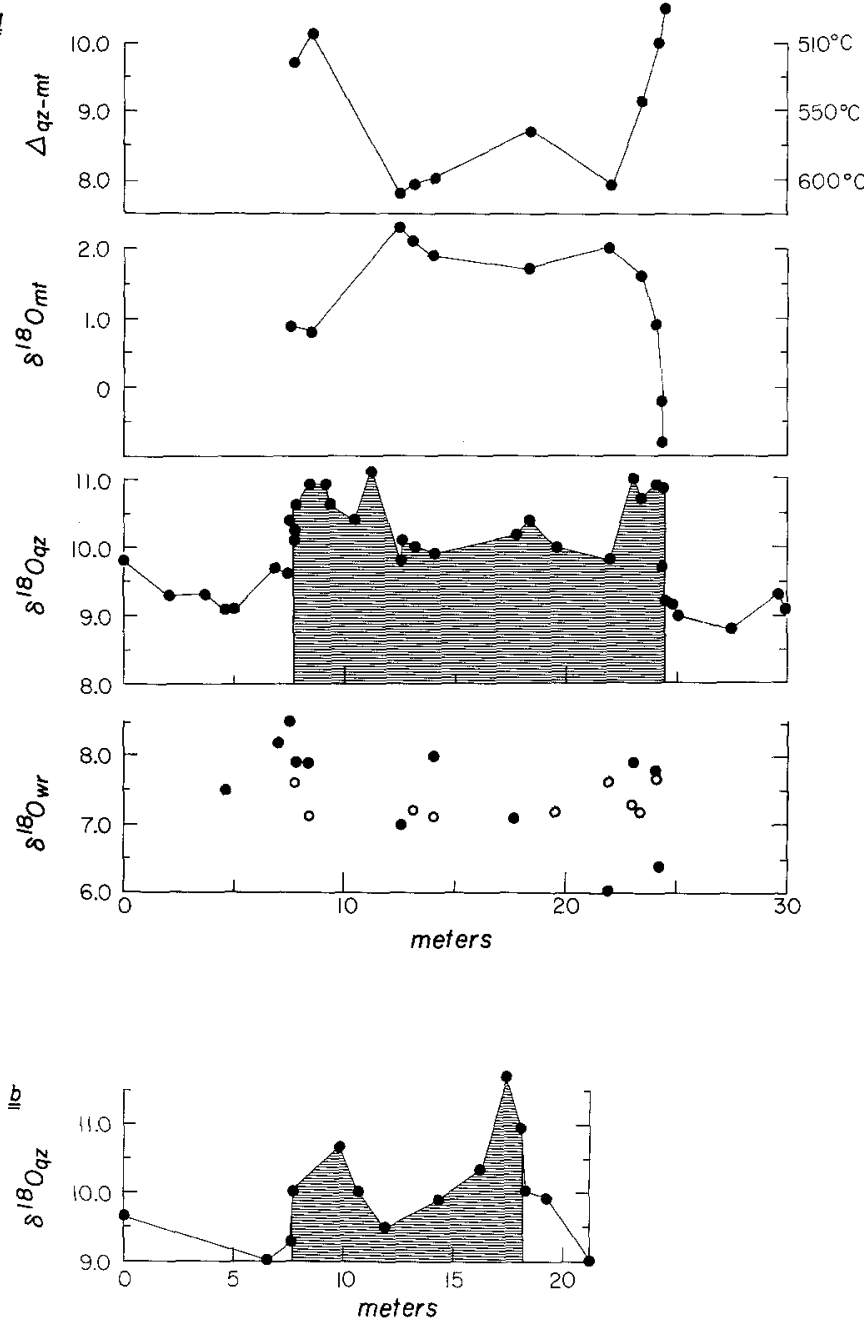

Fig. 4a, b. Isotopic data relative to SMOW for two iron formation boudins and surrounding orthogneiss. a The $\delta^{18} \mathrm{O}_{\mathrm{wr}}$ calculated (open circles) and measured (closed circles) (bottom); $\delta^{18} \mathrm{O}_{\mathrm{qz}}$ in both the iron formation (shaded) and orthogneiss (above whole-rock data); Corresponding $\delta^{18} \mathrm{O}$ values of magnetite from selected samples (above quartz data); Quartz-magnetite fractionations with corresponding temperature estimates using the quartz-magnetite calibration revised by Matthews et al. (1983b) (top); b $\delta^{18} \mathrm{O}$ values for quartz in a different traverse. All data are given in Table 1

the whole rock value can be calculated (or measured). Under closed system conditions, the equilibrium $\delta^{18} \mathrm{O}$ of all minerals can be calculated at any temperature if the fractionation factor for each mineral pair is known. While the isotopic value for each mineral in every sample was not measured, they could be calculated by assuming that all minerals in samples from the marginal portions of the iron formation equilibrated at $500^{\circ} \mathrm{C}$ and minerals in samples from the center of the iron formation equilibrated at $600^{\circ} \mathrm{C}$. The $\delta^{18} \mathrm{O}_{\mathrm{wr}}$ calculated from the sum of the separate mineral values is slightly higher than the measured $\delta^{18} \mathrm{O}_{\mathrm{wr}}$ in most cases (Table 3). The calculated data are preferred, due to the difficulties associated with incomplete sample reaction during whole rock analysis and contamination by late (surficial) oxidation of the whole rock samples. Using the calculated whole-rock data in Table 3 , the isotopic composition of each mineral at $730^{\circ} \mathrm{C}$ was estimated. These estimates must be used with caution due to the compounded uncertainties in making such calculations, but they are nonetheless useful in understanding the prograde history of the terrane. The calculated $\delta^{18} \mathrm{O}_{\mathrm{qz}}$ values at $730^{\circ} \mathrm{C}$ in most samples of the iron formation are nearly constant at $8.7-9.6 \%$ (ave. 9.2 \pm 0.3 ) (Table 3), and are very similar to those of quartz in the surrounding orthogneiss $(9.0-9.6 \%$ ) (ave. 9.4 \pm 0.4 ). These data are consistent with isotopic equilibration during peak metamorphism over tens of meters. The nearly constant whole-rock isotopic values in the iron formation and the surrounding orthogneiss would be expected if large-scale fluid exchange was operative during peak metamorphic conditions.

During retrogression, the degree of equilibration was much more localized. The $\delta^{18} \mathrm{O}_{\mathrm{qz}}$ values in adjacent quartzrich and magnetite-rich layers within a single sample are identical within the precision of the measurements. However, variations are clearly preserved on the meter scale, both within the iron formation and between lithologies. If the peak metamorphic fluid was driven off by upward migration or incorporation into a melt phase, a drying of the terrane would result, with an accompanying reduction in the scale of isotopic re-equilibration.

\section{Retrograde isotopic exchange: Open system}

Open system isotopic exchange of the iron formation involves the introduction of a fluid or melt phase during retrogression. Open system fluid infiltration into the marginal portions of the iron formation may be used to explain the observed isotopic data (Fig. 4) but must satisfy a strict set of isotopic and mineralogical constraints: the $\delta^{18} \mathrm{O}_{\mathrm{wr}}$ must remain constant; the $\delta^{18} \mathrm{O}_{\mathrm{qz}}$ must increase; the $\delta^{18} \mathrm{O}_{\mathrm{mt}}$ must decrease; and orthopyroxenes must not be hydrated. These conditions could be satisfied by the introduction of a $\mathrm{CO}_{2}$-rich fluid that did not change the overall $\delta^{18} \mathrm{O}_{\mathrm{wr}}$, but preferentially exchanged with one or more minerals and not others (e.g. Gregory 1986). This very specific interpretation is not likely in view of the evidence for closed system exchange presented below.

\section{Retrograde isotopic exchange: Closed system}

Oxygen isotope fractionations between metamorphic minerals that imply low formation temperatures could be due to any of the following causes: 1) calibrations of the mineral-pair fractionation factors are incorrect, and the mineral fractionations are actually blocking in at the peak metamorphic temperatures; 2) recrystallization and exchange take place during retrogression, and the isotopic fractionations between minerals record the final recrystallization temperature and; 3) resetting occurs by intracrystalline oxygen diffusion, and the observed fractionations are dependent on the oxygen self-diffusion coefficients and the cooling rate of the terrane. These are treated in order below.

\section{Errors in mineral-pair fractionation factors}

Improperly calibrated fractionation factors cannot explain the low isotopic temperature estimates in the iron formation at Rocking Horse Lake boudins, because, regardless of the calibration, the fractionations between mineral pairs in the central and marginal portions of the iron formation are different. Even if the isotopic ratios of all minerals in the 
Table 2. Temperature estimates corresponding to the isotopic fractionations given in Table 1, based on the calibrations of Matthews et al. (1983b) and Botting and Javoy (1976). See Table 1 for abbreviations

\begin{tabular}{|c|c|c|c|c|c|c|c|c|}
\hline \multirow[t]{2}{*}{ ID \# } & \multicolumn{4}{|c|}{$\mathrm{T}^{\circ} \mathrm{C}$-Matthews et al. } & \multicolumn{4}{|c|}{$\mathrm{T}^{\circ} \mathrm{C}$-Bottinga and Javoy } \\
\hline & $\mathrm{q} z-\mathrm{mt}$ & $\mathrm{qz}-\mathrm{px}$ & $\mathrm{qz}-\mathrm{gn}$ & $\mathrm{px}-\mathrm{mt}$ & $\mathrm{qz}-\mathrm{mt}$ & $\mathrm{qz}-\mathrm{px}$ & $\mathrm{qz}-\mathrm{gn}$ & $\mathrm{px}-\mathrm{mt}$ \\
\hline $2-E$ & 520 & 470 & 500 & 550 & 480 & 560 & 560 & 430 \\
\hline $2-F$ & 510 & - & - & - & 470 & - & - & - \\
\hline $2-G$ & 610 & - & - & - & 570 & - & - & - \\
\hline $2-\mathrm{H}$ & 600 & 560 & 610 & 620 & 540 & 660 & 650 & 490 \\
\hline $2-\mathrm{J}$ & 570 & - & - & - & 500 & - & - & - \\
\hline $2-\mathrm{M}$ & 510 & - & - & - & 470 & - & - & - \\
\hline $2-\mathrm{N}$ & 550 & - & - & - & 510 & - & - & - \\
\hline $\mathrm{T}-\mathrm{O}$ & 490 & - & - & - & 460 & - & - & - \\
\hline $2-4$ & - & 490 & - & - & - & 580 & - & - \\
\hline $2-6$ & 610 & 580 & - & 620 & 540 & 670 & - & 490 \\
\hline $2-9$ & 610 & - & - & - & 570 & - & - & - \\
\hline $2-Y$ & - & 440 & - & - & - & 520 & - & - \\
\hline $1-\mathrm{E}$ & 510 & - & - & - & 470 & - & - & - \\
\hline $1-G$ & 550 & - & - & - & 510 & - & - & - \\
\hline $1-3$ & 530 & - & - & - & 500 & - & - & - \\
\hline $1-4$ & 510 & - & - & - & 470 & - & - & - \\
\hline $1-5$ & 510 & - & - & - & 470 & - & - & - \\
\hline $1-6$ & 510 & - & - & - & 470 & - & - & - \\
\hline
\end{tabular}

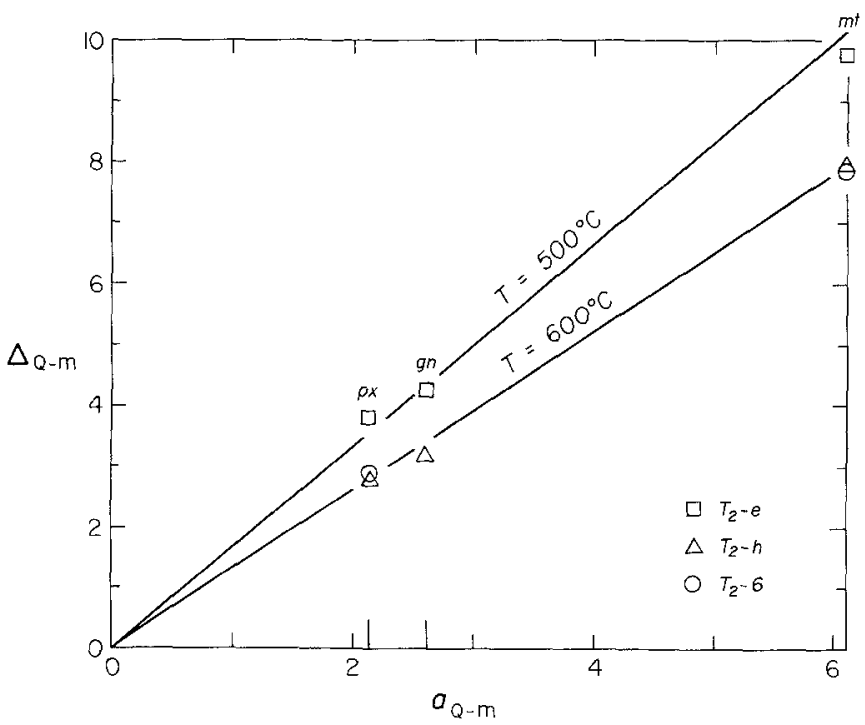

Fig. 5. Isotopic temperature concordance diagram (Javoy et al 1970). The slope of a line passing through the origin is related to the temperature by the equation $\Delta_{\mathrm{Q}-\mathrm{m}}=\mathbf{a}_{\mathrm{Q}-\mathrm{m}} \times 10^{6} / T^{2}$, where $\mathbf{a}$ is the fractionation factor between quartz and the mineral of interest. Concordant temperature estimates from all mineral pairs must lie on a straight line. Fractionation factors from Matthews et al. (1983b) (pyroxene and magnetite) and Matthews and Clayton (unpubl.) (garnet). Abbreviations: quartz $(Q)$, mineral $(m)$, pyroxene $(p x)$, garnet $(g n)$, magnetite $(m t)$

central portion of the iron formation blocked in at the peak temperature of $730^{\circ} \mathrm{C}$, the marginal portions of the iron formation must have been reset. In addition, temperature estimates from other published quartz-magnetite fractionation factors are all within $100^{\circ} \mathrm{C}$ of each other at $\Delta_{\mathrm{qz}-\mathrm{mt}}=$ $8 \%$ (O'Neil and Clayton $1964 ; 650^{\circ} \mathrm{C}$; Bottinga and Javoy $1975 ; 550^{\circ} \mathrm{C}$; Becker and Clayton $1976 ; 550^{\circ} \mathrm{C}$; Downs et al. $1981 ; 600^{\circ} \mathrm{C}$; Matthews et al. $1983 \mathrm{~b} ; 600^{\circ} \mathrm{C}$ ), and temperature estimates from other mineral pairs are all in good agreement (Fig. 5).

\section{Deformation-enhanced recrystallization and exchange}

Stress-related deformation and recrystallization occurring at $500^{\circ} \mathrm{C}$ could explain the observed isotopic ratios in the outer portion of the iron formation. Under the petrographic microscope, quartz grains in the margins of the iron formation appear more deformed, as evidenced by ragged boundaries, varying grain sizes, formation of subgrains and strong undulose extinction. Quartz grains in the central portion of the iron formation are more equant, have sharper grain boundaries, and only a weak undulose extinction (Fig. 6). There is a perfect correspondence of samples with strained quartz and lower isotopic temperatures. In the adjacent migmatite/orthogneiss, quartz does not show this same degree of recrystallization, although direct comparison of the two units is complicated by the different mineralogies.

Deformation and recrystallization of the iron formation within meters of the orthogneiss contact may be explained by differential thermal contraction of the two lithologies, by shearing during boudinage, or by exsolution of a fluid from the orthogneiss during cooling (Savage 1978; Schedl et al. 1986). Kerrich et al. (1977) found that the transition from intercrystalline diffusion to intracrystalline dislocation in a mylonite occurred between 450 and $500^{\circ} \mathrm{C}$. The transition from brittle to ductile behavior is controlled by grain size, strain rate and water fugacity (e.g. Griggs 1974; Bell and Etheridge 1976) and may occur over a wide temperature range (Simpson 1985).

The isotopic profiles in Fig. 4 can be explained solely by the process of deformation-enhanced recrystallization and exchange if deformation occurred down to $500^{\circ} \mathrm{C}$ in the marginal parts of the iron formation boudins, but only $600^{\circ} \mathrm{C}$ in the central parts of the iron formations. All signs of high temperature (i.e. $>600^{\circ} \mathrm{C}$ ) deformation may have been lost by annealing and only the parts of the iron forma- 
Table 3. Measured $\delta^{18} \mathrm{O}_{\mathrm{qz}}$, equilibrium temperature (Teq) inferred from $\Delta \mathrm{qz}-\mathrm{mt}$ values, mineral mode, calculated and measured $\delta^{18} \mathrm{O}_{\mathrm{wr}}$ and calculated $\delta^{18} \mathrm{O}_{92}$ at $730^{\circ} \mathrm{C}$. Modes were determined by $>2000$ point counts per thin section

\begin{tabular}{|c|c|c|c|c|c|c|}
\hline \multirow[t]{2}{*}{ ID \# } & \multirow{2}{*}{$\begin{array}{l}\delta^{18} \mathrm{O}(\mathrm{qz}) \\
\text { obs. }\end{array}$} & \multirow[t]{2}{*}{$\mathrm{T}(\mathrm{eq})$} & \multirow{2}{*}{$\begin{array}{l}\text { mode } \\
q z: m t: p x: g n: o t h e r\end{array}$} & \multicolumn{2}{|c|}{$\delta^{18} \mathrm{O}(\mathrm{wr})$} & \multirow{2}{*}{$\begin{array}{l}\delta^{18} \mathrm{O}(\mathrm{qz}) \\
\left(\mathrm{a} 730^{\circ} \mathrm{C}\right.\end{array}$} \\
\hline & & & & calc & meas & \\
\hline $2-\mathrm{F}$ & 10.9 & $500^{\circ} \mathrm{C}$ & $29: 13: 44: 7^{1}: 7^{2}$ & 7.1 & 7.9 & 9.2 \\
\hline $2-\mathrm{H}$ & 9.9 & $600^{\circ} \mathrm{C}$ & $26: 11: 60: 3$ & 7.1 & 8.0 & 8.7 \\
\hline $2-\mathrm{K}$ & 11.0 & $500^{\circ} \mathrm{C}$ & $51: 22: 13: 14^{3}$ & 7.3 & 7.9 & 9.3 \\
\hline $2-6$ & 10.0 & $600^{\circ} \mathrm{C}$ & $25: 10: 62: 3$ & 7.2 & - & 9.4 \\
\hline $2-8$ & 10.0 & $600^{\circ} \mathrm{C}$ & $28: 8: 60: 4$ & 7.2 & - & 9.2 \\
\hline $2-9$ & 9.8 & $600^{\circ} \mathrm{C}$ & $37: 35: 15: 13^{3}$ & 6.0 & 7.6 & 8.7 \\
\hline
\end{tabular}

${ }^{1}$ plagioclase, ${ }^{2}$ hornblende, ${ }^{3}$ olivine

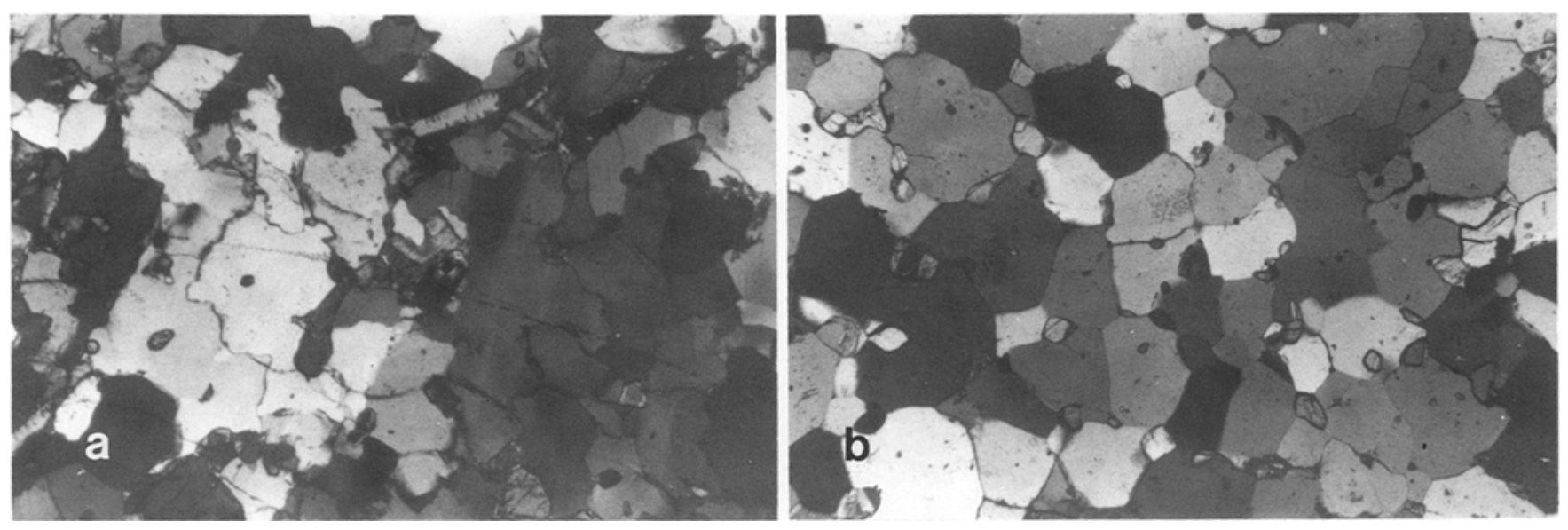

Fig. 6a, b. Photomicrograph of quartz grains in the outer deformed portion of the iron formation (a) and in the central underformed portion of the iron formation (b). Width of each photomicrograph $=2.5 \mathrm{~mm}$. Additional phases are orthopyroxene (high relief) and magnetite (opaque)

tion which were deformed at lower temperatures would preserve deformation features (e.g. Etheridge et al. 1983). The presence of water greatly enhances recrystallization rates in quartz (Hobbs 1968). If a fluid had been present during deformation, quartz grains would probably be totally recrystallized at temperatures of $500^{\circ} \mathrm{C}$.

\section{Oxygen self diffusion}

Intracrystalline self diffusion of oxygen has been measured for many silicates and oxides (e.g. Castle and Surman 1969; Muehlenbachs and Kushiro 1974; Giletti and Anderson 1975; Giletti et al. 1978; Yund and Anderson 1978; Freer and Dennis 1982; Matthews et al. 1983a; Giletti and Yund 1984; Dennis 1984; Farver and Giletti 1985; Giletti 1986b; Elphick et al. 1986). The effect of fluids on oxygen diffusion rates has been clearly demonstrated for some phases (e.g. silica, Spitzer and Ligenza 1961; feldspar, Yund and Anderson 1978). The effect of water on quartz is not clear (e.g. Giletti and Yund 1984; Dennis 1984; Elphick et al. 1986), but if aqueous fluids do enhance diffusion rates in quartz, the profile observed in Fig. 4 could be explained by fluids evolved from the granitic gneiss during cooling (e.g. Konnerup-Madsen 1979; Sandiford and Wilson 1984; Waters and Moore 1985) which then penetrated the outer portions of the iron formation. Diffusion in the dry core would be slower than in the fluid-saturated margins. Although $\mathrm{H}_{2} \mathrm{O}$ rich fluids introduced at $<600^{\circ} \mathrm{C}$ would hydrate the pyroxenes and are ruled out (Fig. 3), $\mathrm{CO}_{2}$-rich fluids are compatible with the preserved mineral assemblages and may enhance diffusion rates similarly to water-rich fluids.

The cooling rate required for self diffusion to continue down to a given isotopic blocking temperature may be calculated if the following are known: 1) The equilibrium isotopic fractionations between all minerals, 2) the diffusion rates in each mineral, and 3 ) the average grain size of each mineral (Dodson 1973; Giletti 1986a). If the cooling rate necessary to allow oxygen exchange to continue down to $600^{\circ} \mathrm{C}$ is unreasonably slow, then oxygen self diffusion cannot contribute significantly to resetting the isotopic values in metamorphic rocks.

In a two phase, closed system composed of a more refractory mineral $a$ and a less refractory mineral $b$, the effect of self diffusion is controlled by the diffusion rate in the more refractory mineral $a$. At very high temperatures $a$ and $b$ will be in isotopic equilibrium, and equilibrium will be maintained down to lower temperatures under conditions of slow cooling. At some reduced temperature, the diffusion rate of oxygen in $a$ will be so low that exchange effectively ceases, and the composition of $a$ is fixed at that 
temperature. The diffusion rate of oxygen in $b$ at the closure temperature of $a$ may still be high, but $b$ has nothing to exchange with and its isotopic composition is also fixed at the blocking (or closure) temperature of $a$. Therefore, the observed isotopic fractionation between $a$ and $b$ will correspond to the temperature at which $a$ closed to further exchange. Because the diffusion rate of minerals is exponentially dependent on temperature, the temperature range over which diffusion effectively stops is small and can be treated as a single temperature for the purposes of calculations (Dodson 1973).

The iron formation at Rocking Horse Lake consists principally of quartz, magnetite and orthopyroxene. By analogy with the very slow diffusion rates in hornblende (Farver and Giletti 1985), it is assumed that the blocking temperature for oxygen diffusion in pyroxene is higher than either in quartz or magnetite. At temperatures below the blocking temperature for pyroxene, the iron formation may be treated as a binary system of quartz and magnetite. If magnetite continued to recrystallize and deform to temperatures below $500^{\circ} \mathrm{C}$, quartz diffusion would be the limiting factor in the exchange rate for quartz-magnetite fractionation. Magnetite deforms plastically down to low temperatures (Siemes 1974; Hennig-Michaeli and Siemes 1975) and is interstitial to quartz and pyroxene in the Wind River iron formations, supporting the argument for low-temperature magnetite recrystallization. Fine exsolution of later hercynite and ilmenite in magnetite provides further evidence for late magnetite recrystallization. For closure of pyroxene at high temperatures and magnetite at low temperatures, the final $\Delta_{\mathrm{qz}-\mathrm{mt}}$ value will be controlled by the closure temperature of quartz. The following calculations were made to test whether isotopic self diffusion is an effective mechanism to explain isotopic resetting, or whether wholesale recrystallization must play a significant role in isotopic resetting of high temperature metamorphic terranes.

Cooling rates were determined by rearranging (23) of Dodson (1973) to the form

$\frac{d T}{d t}=\frac{-A R T_{\mathrm{c}}^{2}\left(D_{0} / a^{2}\right)}{Q \mathrm{e}^{\left(Q / R T_{\mathrm{c}}\right)}}$

where $A=$ diffusional anisotropy parameter $(8.7$ for a infinite sheet), $R=$ gas constant, $T_{\mathrm{c}}=$ isotopic closure temperature, $D_{0}=$ pre-exponential diffusion coefficient, $a=$ half the thickness of the mineral grains (for an infinite sheet) and $Q=$ activation energy. A linear variation of $1 / T$ is assumed over the temperature interval during which time closure takes place, and the mineral of interest (quartz) is assumed to have equilibrated with an infinite reservoir. The latter assumption is reasonable if intercrystalline diffusion is much more rapid than intracrystalline diffusion, and equilibrium between phases is maintained at the interface. The identical $\delta^{18} \mathrm{O}_{\mathrm{qz}}$ values in coexisting quartz-rich and magnetite-rich layers is evidence for rapid intercrystalline diffusion and equilibration over a scale of at least several centimeters. All data using the above equation are given in Table 4 . Cooling rate estimates in ${ }^{\circ} \mathrm{C} / \mathrm{Ma}$ are plotted in Fig. 7 for different temperatures and grain sizes. More rapid cooling rates would result in higher blocking temperatures, while slower cooling rates would permit diffusion to continue down to lower temperatures.

Cooling rates were also calculated assuming that magne-
Table 4. Diffusion data used in Eqs. 6 and 8

\begin{tabular}{lllll}
\hline Mineral & $\begin{array}{l}\text { Do } \\
\mathrm{cm}^{2} / \mathrm{s}\end{array}$ & $\begin{array}{l}\mathrm{D}_{833 \mathrm{~K}} \\
\mathrm{~cm}^{2} / \mathrm{s}\end{array}$ & $\begin{array}{l}Q \\
(\mathrm{~kJ} / \mathrm{mol})\end{array}$ & Source \\
\hline hornblende & $1 \times 10^{-7}$ & $1.8 \times 10^{-18}$ & 172 & $(1)$ \\
magnetite & $1 \times 10^{-6}$ & $2.2 \times 10^{-17}$ & 172 & $(2)$ \\
$\alpha$-quartz* & - & $1.0 \times 10^{-15}$ & - & $(3)$ \\
$\alpha$-quartz & 190 & $3.0 \times 10^{-16}$ & 284 & $(4)$ \\
$\alpha$-quartz & - & $2.6 \times 10^{-16}$ & - & $(5)$ \\
$\alpha$-quartz & 1.90 & $2.5 \times 10^{-18}$ & 280 & $(6)$ \\
\hline
\end{tabular}

* all quartz data parallel to c.

1. Farver and Giletti (1985); 2. Castle and Surman (1969), Giletti (1986b); 3. Dennis (1984); 4. Giletti and Yund (1984); 5. Elphick et al. (1986); 6. This study (calculated for dry diffusion)

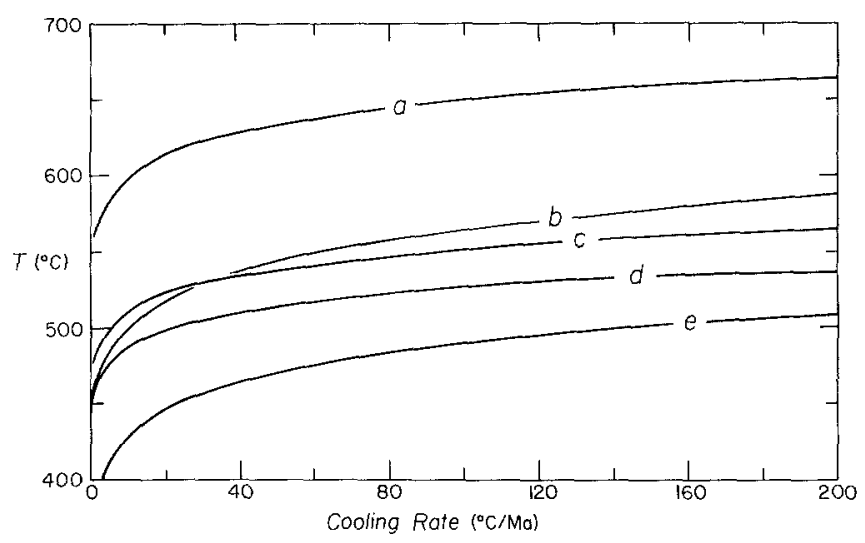

Fig. 7. Cooling rates vs. preserved isotopic temperature following Eq. 5. Curves $a, c$ and $e$ are for $\alpha$-quartz using the diffusion data of Giletti and Yund (1984) for a grain radius of 1.0, 0.1 and $0.05 \mathrm{~cm}$, respectively. Curve $d$ uses the diffusion data of Elphick et al. (1986) for a grain radius of $0.1 \mathrm{~mm}$. Curve $b$ is for magnetite at $0.1 \mathrm{~mm}$ using the combined data of Castle and Surman (1969) and Giletti (1986b)

tite did not undergo recrystallization. In this case, the blocking temperature of magnetite is slightly higher than that of quartz and the magnetite diffusion rate will control the $\Delta_{\mathrm{qz}-\mathrm{mt}}$ values. This difference does not significantly affect the cooling rate estimates (Fig. 7), and the following arguments hold regardless of whether quartz or magnetite is chosen as the rate-limiting mineral for diffusion-controlled exchange.

The calculated cooling rates required to preserve isotopic temperatures of $600^{\circ} \mathrm{C}$ in grains with a radius of $0.5-1.0 \mathrm{~mm}$ are $>800^{\circ} \mathrm{C} / \mathrm{Ma}$ (Fig. 7). Compared to cooling rate estimates of $1-10^{\circ} \mathrm{C} / \mathrm{Ma}$ in similar granulite terranes using ${ }^{40} \mathrm{Ar} /{ }^{39} \mathrm{Ar}$ methods (e.g. Berger and York 1981; Martinez and York 1986; Cosca et al. 1987), the calculated cooling rates using stable isotope methods are unreasonably fast. This conclusion is independent of the complexity of metamorphism in the Wind River Range. If the experimentally determined diffusion rates are appropriate for application to natural assemblages, the record of high temperature isotopic fractionations in the central portion of the iron formation could only be preserved if cooling below $600^{\circ} \mathrm{C}$ was extremely rapid. If the final cooling rate below $600^{\circ} \mathrm{C}$ was slow, then re-equilibration by the process of oxygen 


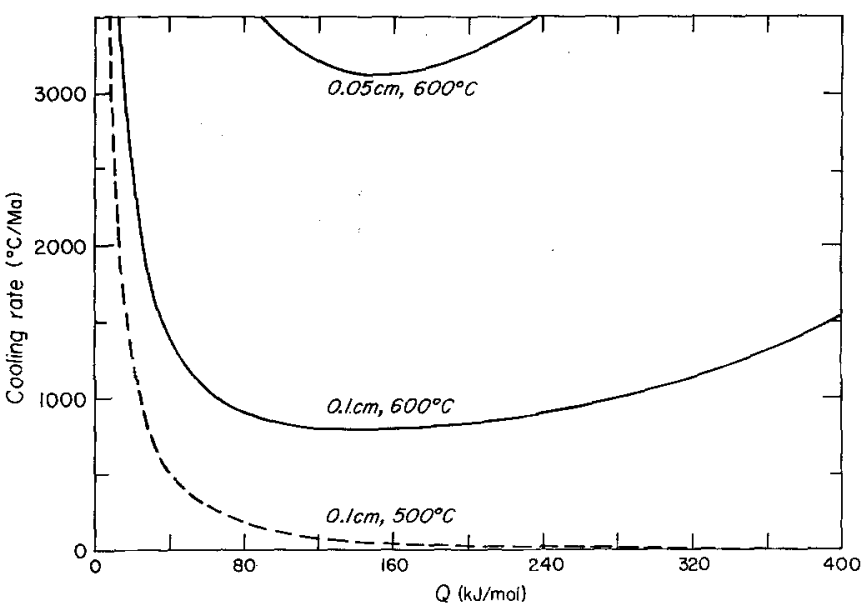

Fig. 8. Values of $Q$ plotted against cooling rate using Eq. 7. At $0.1 \mathrm{~cm}$ grain radius and $600^{\circ} \mathrm{C}$, a minimum cooling rate of $800^{\circ} \mathrm{C}$ is reached when $Q=163 \mathrm{~kJ} / \mathrm{mol}$. Decreasing the grain radius to $0.05 \mathrm{~cm}$ results in a higher minimum cooling rate. Isotopic temperatures of $500^{\circ} \mathrm{C}$ are easily obtainable in geologically reasonable time for a grain radius of $0.1 \mathrm{~cm}$. See text and Table 2 for sources of data

self diffusion would preserve isotopic fractionations corresponding to less than $600^{\circ} \mathrm{C}$. Recrystallization would not alleviate this discrepancy, as it would only enhance the rate of exchange and re-equilibration.

Experimentally determined diffusion coefficients for $\alpha$ quartz were necessarily measured below the $\alpha-\beta$ quartz transition $\left(573^{\circ} \mathrm{C}\right.$ at 1 bar; $599^{\circ} \mathrm{C}$ at $1 \mathrm{kbar}$; Cohen and Klement 1967). The diffusion data of Dennis (1984), Giletti and Yund (1984) and Elphick et al. (1986) are in good agreement in the range $550-595^{\circ} \mathrm{C}$, but are measured over too narrow a temperature range to define an accurate activation energy $(Q)$ and a preexponential diffusion coefficient $\left(D_{0}\right)$ (Elphick et al. 1986). Given an accurate value for $D_{T}$ of $2.5 \times 10^{-16} \mathrm{~cm}^{2} / \mathrm{s}$ at $833 \mathrm{~K}$ (determined from an average of the experimental data), the constants $Q$ and $D_{0}$ can be uniquely defined by combining Eq. (1) with the general Arrhenius equation

$D=D_{0} \mathrm{e}^{\left(-\boldsymbol{Q} / R T_{*}\right)}$

to generate a third equation with the form

$\frac{d T}{d t}=\frac{-A R T_{\mathrm{c}}^{2} D \mathrm{e}^{\left(Q / R T_{*}\right)}}{Q a^{2} \mathrm{e}^{\left(Q / R T_{\mathrm{c}}\right)}}$.

The variable $T_{*}$ is the temperature for the value of $D$ used in Eq. 6, and the other symbols are equivalent to those in Eq. 5. For a cooling rate of $1-10^{\circ} \mathrm{C} / \mathrm{Ma}$ there is no value of $D_{0}$ and $Q$ that will result in a cooling rate of $1-10^{\circ} \mathrm{C} / \mathrm{Ma}$ using the experimental data in Table 4 . A minimum cooling rate of $790^{\circ} \mathrm{C} / \mathrm{Ma}$ is reached when $Q=163 \mathrm{~kJ} / \mathrm{mol}$ and $D_{0}=1.5 \times 10^{-7}$ for the conditions $T_{\mathrm{c}}=600^{\circ} \mathrm{C}, D_{833 \mathrm{~K}}=$ $2.5 \times 10^{-16} \mathrm{~cm}^{2} / \mathrm{s}$, and $\mathrm{a}=0.1 \mathrm{~cm}$ (Fig. 8). In order to preserve the $600^{\circ} \mathrm{C}$ isotopic temperature and have a cooling rate of $10^{\circ} \mathrm{C} / \mathrm{Ma}, D_{833 \mathrm{~K}}$ must be two orders of magnitude lower $\left(2.5 \times 10^{-18} \mathrm{~cm}^{2} / \mathrm{s}\right)$ than the experimentally determined value. Even if magnetite blocked in before quartz, the cooling rates are still more than an order of magnitude too rapid (Fig. 7). This discrepancy may be related to the effect of water on diffusion. If there is a positive correlation between the diffusion rate of oxygen in quartz and water pressure then it is certainly conceivable that diffusion under dry conditions is slow enough to preserve high temperature fractionations.

Cooling rate estimates for the two iron formations retrograded under water-rich conditions and preserving $500^{\circ} \mathrm{C}$ isotopic temperatures are $10-40^{\circ} \mathrm{C} / \mathrm{Ma}$. These cooling rates are consistent with the experimental diffusion data and suggest that water enhances the diffusion rate of oxygen in quartz under water-present conditions. However, late deformation in these small, water-saturated boudins may instead account for the low isotopic temperatures.

\section{Discussion}

Giletti and Yund (1984) determined that the diffusion rate of oxygen in $\beta$-quartz is dependent on water fugacity, and that the diffusion coefficient $D_{\beta \text { quartz }}$ at 1 bar $f \mathrm{H}_{2} \mathrm{O}$ is $1 \log$ unit $\left(\mathrm{cm}^{2} / \mathrm{s}\right)$ less than at $1 \mathrm{kbar}$. Dennis (1984) performed similar experiments and found no such correlation. Both of these experiments considered the diffusional interface between the polished surface of quartz and an ${ }^{18} \mathrm{O}$-enriched hydrothermal fluid. Elphick et al. (1986) were concerned with submicron recrystallization at the quartz-fluid interface in the earlier experiments, and they avoided the problem by measuring the diffusion profile between a polished quartz face and an ${ }^{18} \mathrm{O}$-enriched quartz overgrowth. Unfortunately, the experiments of Elphick et al. (1986) were run at $1 \mathrm{kbar}$ only and cannot be used to eliminate the discrepancy between the two earlier experiments.

No strong correlation between the pressure (or fugacity) of water and diffusion rate was observed in any recent diffusion experiments on quartz using secondary ion mass spectrometry (SIMS) techniques (Dennis 1984; Giletti and Yund 1984; Elphick et al. 1986). In contrast, a strong effect of water pressure on the diffusion rate of oxygen in feldspar has been observed. Yund and Anderson (1978) found the diffusion rate of oxygen in adularia to be linearly dependent on water pressure above 200 bars, and drop off substantially below 200 bars. A smaller dependence was observed in more recent experiments over a wider pressure range (Dennis and Freer 1986). Dry exchange experiments on anorthite (Muehlenbachs and Kushiro 1974; Elphick and Dennis 1986) correspond to diffusion rates several orders of magnitude less than for hydrothermal conditions (Giletti et al. 1978). Oxygen diffusion rate estimates in quartz exchanged with $\mathrm{CO}_{2}$ (or $\mathrm{O}_{2}$ ) using neutron activation (Choudhury et al. 1965) and bulk exchange (Schachtner and Sockel 1977) are also much lower than those exchanged with $\mathrm{H}_{2} \mathrm{O}$. Unfortunately, the experimental methods used for dry diffusion experiments are less precise than the SIMS method, and the two cannot be compared directly (Dennis 1984). While there is disagreement between the diffusion studies, it appears that the presence or absence of water has a more dramatic effect on diffusion than do actual variations in water pressure.

The pressure dependence observed in diffusion experiments between amorphous silica and ${ }^{18} \mathrm{O}$-enriched steam is attributed to interstitial water entering the lattice and exchanging with bound oxygen by the formation of $\mathrm{Si}-$ $\mathrm{OH}-\mathrm{OH}-\mathrm{Si}$ bonds (Spitzer and Ligenza 1961). The void volume in quartz is significantly less than in amorphous silica, and the importance of interstitial water may be much less. If water or hydrogen is the principal catalyst for oxy- 
gen diffusion in quartz, rocks metamorphosed under $\mathrm{CO}_{2}$ or fluid-absent conditions would equilibrate at a much slower rate than rocks metamorphosed in the presence of a water-rich fluid. Retrogression in most of the iron formation at Rocking Horse Lake occurred under either dry conditions or in the presence of a $\mathrm{CO}_{2}$-rich fluid. Only the small iron formation lenses show any evidence of late waterrich fluids. If $\mathrm{CO}_{2}$, like $\mathrm{H}_{2} \mathrm{O}$, enhances the diffusion rate of oxygen, then isotopic temperatures of $600^{\circ} \mathrm{C}$ in the central portion of the iron formation could not be preserved if a $\mathrm{CO}_{2}$-rich fluid was present, and the metamorphism must have occurred in the absence of a fluid phase. If $\mathrm{CO}_{2}$ does not enhance oxygen diffusion rates as water does, then the preserved isotopic fractionations in granulites can be used as a sensor of a water-rich fluid.

\section{Conclusions}

Recrystallization appears to drive low-temperature isotopic re-equilibration in the marginal portions of the iron formation at Rocking Horse Lake, but the effect of oxygen self diffusion may account for the retrograde metamorphic temperatures in the central, "undeformed" portion of the iron formations. Oxygen self diffusion alone would result in isotopic fractionation temperatures of $<500^{\circ} \mathrm{C}$ if the experimentally determined diffusion coefficients are correct. The diffusion coefficient $D$ must be significantly less than the measured value in order to preserve fractionations corresponding to $600^{\circ} \mathrm{C}$. A pronounced effect on the diffusion rate by a fluid phase probably accounts for this discrepancy, and this conclusion is independent of the complexity of the terrane. No matter how many metamorphic events were operative in the Wind River terrane, isotopic fractionations corresponding to $600^{\circ} \mathrm{C}$ temperatures could only be preserved if the final cooling event was as rapid as $800^{\circ} \mathrm{C} / \mathrm{Ma}$.

The results of this study suggest that recrystallization and diffusion under fluid-present conditions may explain the low "isotopic temperatures" observed in virtually all granulite facies rocks. Once the effect of fluids and deformation are unraveled, oxygen isotope fractionations can be used to indicate fluid presence and elucidate retrograde deformation histories in amphibolite- and granulite facies rocks. Further work is required to determine the effects of fluids on oxygen self diffusion rates. Because diffusion under dry conditions may be very slow, laboratory experiments might not be practical. Metamorphic lithologies that constrain fluid compositions or were necessarily dry should be investigated to evaluate the effects of fluids. An isotopic study of a lithology increasing from fluid-present amphibolite- to fluid-absent granulite facies may potentially resolve the effect of fluids on diffusion rates. Iron formations are ideal lithologies for these studies because the oxygen isotope fractionation between the principal minerals, quartz and magnetite, are sensitive to changes in temperature.

Acknowledgments. This work was supported in part by NSF grant EAR- 8408168 to E.J.E. The authors thank R. Brigham and L. Adami for their assistance with isotopic analyses. Special thanks are due for M. Cosca and G. Helffrich for their help with the field work. The reviews of E. Erslev, C. Frost, S. Sharp and an anonymous reviewer were helpful and appreciated as was the editorial handling of Z. Peterman. The electron microprobe analyzer used in this work was acquired under NSF grant EAR-82-12764.

\section{References}

Anderson AT (1967) The dimensions of oxygen isotopic equilibrium attainment during prograde metamorphism. J. Geol 75:323-332

Bassett WA, Giletti BJ (1963) Precambrian ages in the Wind River Mountains, Wyoming. Geol Soc Am Bull 74:209-212

Becker RH, Clayton RN (1976) Oxygen isotope study of a Precambrian banded iron-formation, Hamersley Range, Western Australia. Geochim Cosmochim Acta 40:1153-1165

Bell TH, Etheridge MA (1976) The deformation and recrystallization of quartz in a mylonite zone, central Australia. Tectonophysics 32:235-267

Berg RR, Romberg FE (1966) Gravity profile across the Wind River Mountains, Wyoming. Geol Soc Am Bull 77:647-656

Berger GW, York D (1981) Geothermometry from ${ }^{40} \mathrm{Ar} /{ }^{39} \mathrm{Ar}$ dating experiments. Geochim Cosmochim Acta 45:795-811

Blacic JD, Christie JM (1984) Plasticity and hydrolytic weakening of quartz single crystals. J Geophys Res 89:4223-4239

Bohlen SR, Essene EJ, Boettcher AL (1980) Reinvestigation and application of olivine-quartz-orthopyroxene barometry. Earth Plan Sci Lett 47:1-10

Bohlen SR, Boettcher AL (1981) Experimental investigations and geological applications of orthopyroxene geobarometry. Am Mineral 66:951-964

Bohlen SR, Wall VJ, Boettcher AL (1983 a) Experimental investigation and application of garnet granulite equilibria. Contrib Mineral Petrol 83:52-61

Bohlen SR, Meth GW, Essene EJ, Anovitz LM, Westrum EF, Wall VJ (1983b) Thermodynamics and phase equilibrium of ferrosilite: potential oxygen barometers in mantle rocks. Trans Am Geophys Union 64:350

Bohlen SR, Wall VJ, Boettcher AL (1983c) Experimental investigations and geological applications of equilibria in the system $\mathrm{FeO}-\mathrm{TiO}_{2}-\mathrm{Al}_{2} \mathrm{O}_{3}-\mathrm{SiO}_{2}-\mathrm{H}_{2} \mathrm{O}$. Am Mineral 68:1049-1058

Borthwick J, Harmon RS (1982) A note regarding $\mathrm{ClF}_{3}$ as an alternative to $\mathrm{BrF}_{5}$ for oxygen isotopic analysis. Geochim Cosmochim Acta 46:1665-1668

Bottinga Y, Javoy M (1975) Oxygen isotope partitioning among the minerals in igneous and metamorphic rocks. Rev Geophys Space Phys 13:401-418

Bowman JR, Ghent ED (1985) Oxygen and hydrogen isotope study of minerals from metapelitic rocks, staurolite to sillimanite zones, Mica Creek, British Columbia. Geol Soc Abstr w/Prog 17:529

Castle JE, Surman PL (1969) The self-diffusion of oxygen in magnetite. The effect of anion vacancy concentration and cation distribution. J Phys Chem 73:632-634

Choudhury A, Palmer PW, Amsel G, Curien H, Baruch P (1965) Study of oxygen diffusion in quartz using the nuclear reaction $\mathrm{O}^{18}(p, \alpha) \mathrm{N}^{15}$. Sold State Commun 3:119-122

Cosca MA, Essene EJ, Sutter JF (1987) Denudation rates of Grenville basement near Parry Sound, Ontario: Constraints from ${ }^{40} \mathrm{Ar} /{ }^{39} \mathrm{Ar}$ thermochronology. Trans Am Geophys Union 68:432

Cohen LH, Klement W JR (1967) High-low quartz inversion: determination to 35 kilobars. J Geophys Res 72:4245-4251

Cole DR, Ohmoto H, Lasaga AC (1983) Isotopic exchange in mineral-fluid systems. I. Theoretical evaluation of oxygen isotopic exchange accompanying surface reactions and diffusion. Geochim Cosmochim Acta 47:1681-1693

Davy R (1983) Part A. A contribution on the chemical composition of Precambrian iron-formations. In: Trendall AF, Morris RC (eds) Iron Formations: Facts and Problems. Elsevier, Amsterdam, pp 325-344

Dennis PF (1984) Oxygen self-diffusion in quartz under hydrothermal conditions. J Geophys Res 89:4047-4057

Dennis PF, Freer R (1986) Oxygen self diffusion kinetics and mechanisms in albite and adularia feldspars under hydrothermal conditions. Experimental Mineral Geochem, International Symposium 48-49 
Dodson MH (1973) Closure temperature in cooling geochronological and petrological systems. Contrib Mineral Petrol $40: 259-274$

Downs WF, Touysinhthiphonexay Y, Deines P (1981) A direct determination of the oxygen isotope fractionation between quartz and magnetite at 600 and $800^{\circ} \mathrm{C}$ and $5 \mathrm{kbar}$. Geochim Cosmochim Acta 45:2065-2072

Ellis DJ, Green DH (1979) An experimental study of the effect of $\mathrm{Ca}$ upon garnet-clinopyroxene $\mathrm{Fe}-\mathrm{Mg}$ exchange equilibria. Contrib Mineral Petrol 71:13-22

Elphick SC, Dennis PF (1986) "Wet" vs "dry" oxygen diffusion in anorthite, and its geological implications. Experimental Mineral Geochem, International Symposium 56-57

Elphick SC, Dennis PF, Graham CM (1986) An experimental study of the diffusion of oxygen in quartz and albite using an overgrowth technique. Contrib Mineral Petrol 92:322-330

Etheridge MA, Wall VJ, Vernon RH (1983) The role of fluid phase during regional metamorphism and deformation. J Metamorphic Geol 1:205-226

Farver JR, Giletti BJ (1985) Oxygen diffusion in amphiboles. Geochim Cosmochim Acta 49:1403-1411

Freer R, Dennis PF (1982) Oxygen diffusion studies. I. A preliminary ion microprobe investigation of oxygen diffusion in some rock-forming minerals. Min Mag 45:179-192

French BM (1966) Some geological implications of equilibrium between graphite and a $\mathrm{C}-\mathrm{H}-\mathrm{O}$ gas phase at high temperatures and pressures. Rev Geophys 4:223-253

Giletti BJ (1985) The nature of oxygen transport within minerals in the presence of hydrothermal water and the role of diffusion Chem Geol 53:197-206

Giletti BJ (1986a) Diffusion effects on oxygen isotope temperatures of slowly cooled igneous and metamorphic rocks. Earth Plan Sci Lett $77: 218-228$

Giletti BJ (1986b) Cooling rates derived from $A^{18} \mathrm{O}$ of minerals in igneous and metamorphic rocks. Geol Soc Am Abstr w/Prog $18: 614$

Giletti BJ, Anderson TF (1975) Studies in diffusion, II. Oxygen in phlogopite micas. Earth Plan Sci Lett 28:225-233

Giletti BJ, Yund RA (1984) Oxygen diffusion in quartz. J Geophys Res 89:4039-4046

Giletti BJ, Semet MP, Yund RA (1978) Studies in diffusion, III. Oxygen in feldspars, an ion microprobe determination. Geochim Cosmochim Acta 42:45-57

Gregory RT (1986) Oxygen isotope systematics of quartz-magnetite pairs from Precambrian iron formations: Evidence for fluid-rock interaction during diagenesis and metamorphism. In: Walther JV, Wood BJ (eds) Advances in physical geochemistry fluid-rock interactions during metamorphism. Springer-Verlag, New York, pp 132-153

Griggs DT (1967) Hydrolytic weakening of quartz and other silicates. Geophys J R Astron Soc 14:19-31

Griggs DT (1974) A model of hydrolytic weakening in quartz. J Geophys Res 79:1653-1661

Haselton HT JR, Hovis GL, Hemingway BS, Robic RA (1983) Calorimetric investigation of the excess entropy of mixing in analbite-sanidine solid solutions: lack of evidence for $\mathrm{Na}, \mathrm{K}$ short-range order and implications for two-feldspar thermometry. Am Min 68:398-413

Hennig-Michaeli Ch, Siemes H (1975) Zwillingsgleitung beim Magnetit. N Jb Miner Abh 123:330-334

Hobbs BE (1968) Recrystallization of single crystals of quartz. Tectonophysics 6:353-401

Javoy M, Fourcade S, Allegre CJ (1970) Graphical method for examination of ${ }^{18} \mathrm{O} /{ }^{16} \mathrm{O}$ fractionations in silicate rocks. Earth Plan Sci Lett 10:12-16

Kerrich R, Beckinsale RD, Durham JJ (1977) The transition between deformation regimes dominated by intercrystalline diffusion and intracystalline creep evaluated by oxygen isotope thermometry. Tectonophysics $38: 241-257$

Klein C (1983) Diagenesis and metamorphism of Precambrian banded iron formations. In: Trendall AF, Morris RC (eds)
Iron Formations: Facts and Problems. Elsevier, Amsterdam, pp $417-470$

Konnerup-Madsen J (1979) Fluid inclusion in quartz from deepseated granitic intrusions, south Norway. Lithos 12:13-23

Koziol AM, Newton RC (1986) Definition of anorthite= grossular + kyanite + quartz in the range $650^{\circ}-1250^{\circ} \mathrm{C}$. Geol Soc Am Abstr w/Prog 18:661

Krylov DP (1982) Oxygen isotope distribution in polymetamorphic complexes. Geochim Intl 6:31-36

Lee HY, Ganguly J (1987) Equilibrium compositions of coexisting garnet and orthopyroxene: reversed experimentsal determinations in the system $\mathrm{FeO}-\mathrm{MgO}-\mathrm{Al}_{2} \mathrm{O}_{3}-\mathrm{SiO}_{2}$, and applications. J Petrol (in press)

Martinez ML, York D (1986) $\mathrm{A}^{40} \mathrm{Ar} /{ }^{39} \mathrm{Ar}$ age study of the Kapuskasing structural zone. Geol Assoc Can Prog w/Abstr 11:96

Matsuhisa Y, Goldsmith JR, Clayton RN (1979) Oxygen isotope fractionation in the system quartz-albite-anorthite-water. Geochim Cosmochim Acta 43:1131-1140

Matthews A, Goldsmith JR, Clayton RN (1983a) On the mechanisms and kinetics of oxygen isotope exchange in quartz and feldspars at elevated temperatures and pressures. Geol Soc Am Bull 94:396-412

Matthews A, Goldsmith JR, Clayton RN (1983b) Oxygen isotope fractionation involving pyroxenes: the calibration of mineralpair geothermometers. Geochim Cosmochim Acta 47:631-644

Muehlenbachs K, Kushiro I (1974) Oxygen isotope exchange and equilibrium of silicates with $\mathrm{CO}_{2}$ or $\mathrm{O}_{2}$. Carnegie Inst Washington Yearb $73: 232-236$

Naylor RS, Steiger RH, Wasserburg GJ (1970) U-Th-Pb and $\mathrm{Rb}-\mathrm{Sr}$ systematics in $2700 \times 10^{6}$ year old plutons from the southern Wind River Range, Wyoming. Geochim Cosmochim Acta 34:1139-1159

Oftendahl C (1953) Petrologic reconnaissance in the Pre-Cambrian of the western part of the Wind River Mountains, Wyoming. Norsk Geol Tidsskrift, 32:1-17

O’Neil JR (1963) Oxygen Isotope Fractionation Studies in Mineral Systems. PhD thesis, Univ Chicago

O'Neil JR (1986) Theoretical and experimental aspects of isotope fractionation. In: Valley JW, Taylor HP JR, O'Neil JR (eds) Stable isotopes in high temperature geological processes. Reviews in Mineralogy Vol 16. Mineral Soc Am, Washington, DC, pp $1-40$

O'Neil JR, Clayton RN (1964) Oxygen isotope geothermometry. In: Craig H, Miller SL, Wasserburg GJ (eds) Isotopic and cosmic chemistry. North Holland, Amsterdam, pp 157-148

Perry EC JR, Ahmad SN, Swulius TM (1978) The oxygen isotope composition of $3,800 \mathrm{~m} . \mathrm{y}$. old metamorphosed chert and iron formation from Isukasia, West Greenland. J Geol 86:223-239

Richmond G (1945) Geology of the northwest end of the Wind River Mountains. US Geol Survey Ol map 31

Rumble D III (1982) Stable isotope fractionation during metamorphic volatilization reactions. In: Ferry JM (ed) Characterization of Metamorphism Through Mineral Equilibria. Reviews in Mineralogy Vol 10, Mineral Soc Am Washington DC, pp 153-206

Sandiford M, Wilson CJL (1984) The structural evolution of the Fyfe Hills-Khmara Bay region, Enderby Land, East Antarctica. Aust J Earth Sci 31:403-426

Savage WC (1978) The development of residual stress in cooling rock bodies. Geophys Res Lett 5:633-636

Schachtner R, Sockel HG (1977) Study of oxygen diffusion in quartz by activation analysis. In: Wood $\mathrm{J}$, Lindquist $\mathrm{O}$, Helgeson C, Vannerburg NG (eds) Reactivity of Solids, Proceeding International Symposium (8th). Plenum, New York, pp 605609

Schedl A, Kronenberg AK, Tullis J (1986) Deformation microstructures of Barre Granite: an optical, SEM and TEM study. Tectonophysics 122:149-164

Sen SA, Bhattacharya A (1984) An orthopyroxene-garnet thermometer and its application to the Madras charnockites. Contrib Mineral Petrol 88:64-71 
Sharp ZD, Essene EJ (1984) A low pressure granulite facies taconite: implications for Archean heat flow. Geol Soc Am Abstr w/Prog 16:651

Shieh YN (1974) Mobility of oxygen isotopes during metamorphism. In: Geochemical Transport and Kinetics. Carnegie Inst Washington Publ 634:325-335

Siemes H (1974) Anwendung der Taylor-Theorie auf die Regelung von kubischen Mineralen. Contrib Mineral Petrol 43:149-157

Simpson C (1985) Deformation of granitic rocks across the brittleductile transition. J Struct Geol 7:503-511

Simpson C, Segall P (1984) The role of fractures in the nucleation and propagation of shear zones in granite. Geol Soc Am Abstr w/Prog 16:657

Smithson SB, Brewer JA, Kaufman S, Oliver JE, Zawislak RL (1980) Complex Archean lower crustal structure revealed by COCORP crustal reflection profiling in the Wind River Range, Wyoming. Earth Plan Sci Lett 46:295-305

Spitzer WG, Ligenza JR (1961) Oxygen exchange between silica and high pressure steam. J Phys Chem Solids 17:196-202

Stuckless JS, Hedge CE, Worl RG, Simmons KR, Nkomo IT, Wenner DB (1985) Isotopic studies of the late Archean plutonic rocks of the Wind River Range, Wyoming Geol Soc Am Bull $96: 850-860$

Valley JW (1986) Stable isotope geochemistry of metamorphic rocks. In: Valley JW, Taylor HP JR, O'Neil JR (eds) Stable Isotopes in High Temperature Geological Processes. Reviews in Mineralogy Vol 16. Mineral Soc Am, Washington, DC, pp $445-490$

Waters DJ, Moore JM (1985) Kornerupine in Mg - Al-rich gneisses from Namaqualand, South Africa: mineralogy and evidence for late-metamorphic fluid activity. Contrib Mineral Petrol 91:369-382

Worl RG (1968) Taconite in the Wind River Mountains, Sublette County, Wyoming, Wyoming Geol Surv Prel Rep 10,15 p

Worl RG, Lee GK, Long CL, Ryan GS (1984) Mineral resource potential of the Bridger Wilderness and Green-Sweetwater Roadless Area, Sublette and Fremont counties, Wyoming. Misc Field Stud Map MF-1636-A, US Geol Surv, 12 p

Yund RA, Anderson TF (1974) Oxygen isotope exchange between potassium feldspar and $\mathrm{KCl}$ solution. In: Hoffman $\mathrm{AW}$, Giletti BJ, Yoder HS JR, Yund RA (eds) Geochemical Transport and Kinetics. Carnegie Inst Washington Publication 634:99-105

Yund RA, Anderson TF (1978) Oxygen isotope exchange between feldspar and fluid as a function of fluid pressure. Geochim Cosmochim Acta 42:235-239

Received May 6, 1987/Accepted November 23, 1987

Editorial responsibility: Z. Peterman 